\title{
$\overline{\text { Vol. } 12 \text { No. } 3 \text { September } 1990}$
}
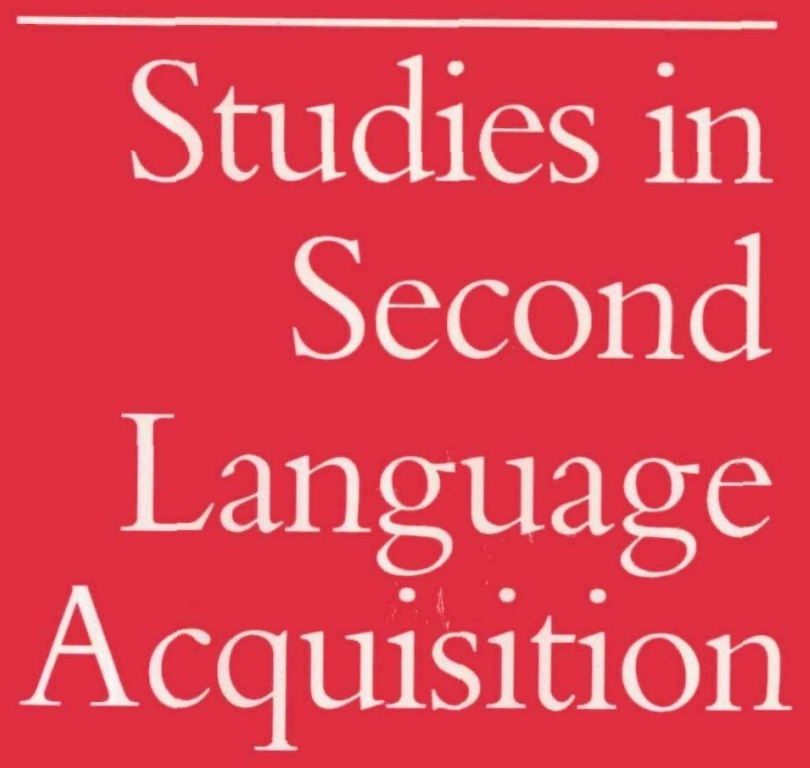

Cambridge University Press 


\title{
STUDIES IN SECOND LANGUAGE ACQUISITION
}

\author{
Editor, Albert Valdman, Indiana University \\ Review Editor, Susan Gass, Michigan State University \\ Assistant to the Editor, Charles Pooser, Indiana University
}

\section{Editorial Board}

Roger Andersen (UCLA), Andrew Cohen (Hebrew University), Rod Ellis (Temple University, Japan), Gabriele Kasper (University of Hawaii, Manoa), Michael Long (University of Hawaii, Manoa), Barry McLaughlin (University of California, Santa Cruz), Jürgen M. Meisel (University of Hamburg), Lydia White (McGill University)

\section{Advisory Committee}

Vivian Cook (University of Essex), Eric Kellerman (University of Nijmegen), Claire Kramsch (University of California, Berkeley), Stephen Krashen (USC), James P. Lantolf (University of Delaware), Patsy Lightbown (Concordia University), Teresa Pica (University of Pennsylvania), John H. Schumann (UCLA), Peter Skehan (University of London), G. Richard Tucker (Center for Applied Linguistics, Washington, DC), Bill VanPatten (University of Illinois, Urbana-Champaign), Daniel Véronique (Université de Provence)

\section{EDITORIAL POLICY}

Studies in Second Language Acquisition is devoted to problems and issues in second language acquisition and foreign language learning, defined broadly to include problems of language contact-interference, transfer, pidginization. While preference will be given to theoretically-oriented papers and reports of empirical research, discussions of pedagogical issues will be considered if they refer to major theoretical issues in the field. Studies in Second Language Acquisition is a refereed publication. Submitted material undergoes blind evaluation by at least two readers selected from the members of the Editorial Board, Advisory Committee, and other experts in the field. The names of all outside readers consulted will be listed in the final issue of each volume.

\section{PUBLISHING, PRODUCTION, AND ADVERTISING OFFICES}

Cambridge University Press, 40 West 20th Street, New York, NY 10011, U.S.A.; or Cambridge University Press, The Edinburgh Building, Shaftesbury Road, Cambridge CB2 2RU, England.

\section{SUBSCRIPTION OFFICES}

(For U.S.A. and Canada) Cambridge University Press, 110 Midland Avenue, Port Chester, NY 10573, U.S.A. (For U.K. and elsewhere) Cambridge University Press, The Edinburgh Building, Shaftesbury Road, Cambridge CB2 2RU, England.

\section{SUBSCRIPTION INFORMATION}

Studies in Second Language Acquisition (ISSN 0272-2631) is published four times a year. Annual subscription rates for Volume 12 (1990): Institutions, US $\$ 69.00$ in the U.S.A. and Canada, UK $\$ 41.00$ in the U.K. and Eire, and UK $£ 45.00$ elsewhere; Individuals, US $\$ 37.00$ in the U.S.A. and Canada, and UK

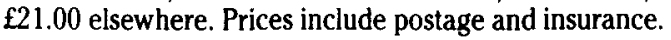

\section{CAMBRIDGE UNIVERSITY PRESS}

All rights reserved. No part of this publication may be reproduced, in any form or by any means, electronic, photocopying, or otherwise, without written permission from Cambridge University Press. Photocopying information for users in the U.S.A.: The Item-Fee Code for this publication (0272-2631/90 $\$ 5.00+.00$ ) indicates that copying for internal or personal use beyond that permitted by Sec. 107 or 108 of the U.S. Copyright Law is authorized for users duly registered with the Copyright Clearance Center (CCC) Transaction Reporting Service, provided that the appropriate remittance of $\$ 5.00$ per article is paid directly to: CCC, 27 Congress Street, Salem, MA 01970. Specific written permission must be obtained for all other copying. Contact the ISI Tearsheet Service, 3501 Market Street, Philadelphia, PA 19104, for single copies of separate articles. 


\title{
TABLE OF CONTENTS
}

\author{
STATE OF THE ART
}

Maturational Constraints on Language Development Michael H. Long

\section{ARTICLES}

Attending to Form and Content in the Input: An Experiment in Consciousness

Bill VanPatten

Speech Rate Is No Simple Matter: Rate Adjustment and NS-NNS

Communicative Success

Tracey M. Derwing

The Primacy of Aspect: Aspectual Marking in English Interlanguage

Richard E. Robison

\section{REVIEW ARTICLE}

Universal Grammar and Second Language Acquisition Theory: A Review of a Research Framework and Two Exemplary Books

David Birdsong

\section{REVIEWS}

Philips, S. U., Steele, S., \& Tanz, C. (Eds.). (1987). Language, gender, and sex in comparative perspective (Kathleen Geissler)

Lowenthal, F., \& Vandamme, F. (Eds.). (1986). Pragmatics and education (Robert S. Burton)

Dromi, E. (1987). Early lexical development (Julia S. Falk)

Brown, J. D. (Ed.). (1988). Understanding research in second language learning: A teacher's guide to statistics and research design (Miriam R. Eisenstein)

Bates, E., Bretherton, I., \& Snyder, L. (1988). From first words to grammar: Individual differences and dissociable mechanisms (Julia S. Falk)

Coulmas, F. (Ed.). (1988). With forked tongues: What are national languages good for? (Braj B. Kachru)

Clahsen, H. (1988). Normale und gestörte Kindersprache (Lynn Eubank) 
Adamson, H. D. (1988). Variation theory and second language acquisition (Robert M. DeKeyser)

Catford, J. C. (1988). A practical introduction to phonetics (Ruth M. Brend)

Green, J. L., \& Harker, J. O. (Eds.). (1988). Multiple perspective analyses of classroom discourse: Volume XXVIII, Advances in discourse processes (Nancy Ainsworth-Vaughn)

Coupland, N. (Ed.). (1988). Styles of discourse (John Swales)

Hornberger, N. H. (1988). Bilingual education and language maintenance: A southern Peruvian Quechua case (Carolyn Kessler)

Rosenberg, S. (Ed.). (1987). Advances in applied psycholinguistics: Volume 2, Reading, writing and language learning (Ellen Block)

Aksu-Koç, A. (1988). The acquisition of aspect and modality: The case of past reference in Turkish (Jeanette $\mathrm{S}$. DeCarrico)

Jordens, P., \& Lalleman, J. (Eds.). (1988). Language development (Julia S. Falk)

Roberts, P. (1988). West Indians and their language (Pauline Christie)

Fishman, J. A., Tabouret-Keller, A., Clyne, M., Krishnamurti, Bh., \& Abdulaziz, M. (Eds.). (1986). The Fergusonian impact: In honor of Charles A. Ferguson on the occasion of his 65 th birthday (2 vols.) (Grover Hudson)

Nehls, D. (Ed.). (1987). Interlanguage studies (Harry L. Gradman)

\section{BOOK NOTICES}

Van Roey, J., Granger, S., \& Swallow, H. (1988). Dictionnaire des faux amis: Français-anglais (Natalie Lefkowitz)

Hammarberg, B. (1988). Studien zür Phonologie des Zweitsprachenerwerbs (Marcel Danesi)

Newby, M. (1987). The structure of English: A handbook of English grammar (Sarah Burn)

Tinkel, A. J. (1988). Explorations in language (Susan Gass)

Cosnier, J., \& Kerbrat-Orecchioni, C. (Eds.). (1987). Décrire la conversation (Penelope Gardner-Chloros)

Garvie, E. (1990). Story as vehicle: Teaching English to young children (Denise E. Phillippe) 